\title{
Stock Market Integration in Africa: The Case of the Johannesburg Stock Exchange and Selected African Countries
}

Gail Ncube, University ofp Fort Hare, South Africa

Kapingura Forget Mingiri, University of Fort Hare, South Africa

\begin{abstract}
African stock markets are deemed to be small, segmented and illiquid. Given this back ground, the study utilises monthly data for the period 2000-2008, employing the Johansen and Julius cointegration method to determine the long-run relationship between the five selected African stock markets. Granger causality tests were also conducted to establish if there are any causal links between the stock markets in Africa. The analysis in the study indicates that African stock markets are improving in performance, generally, growing and developing. However empirical results indicate that African markets are segmented. Further analysis to determine the relationship between the five selected African stock markets and the world stock markets shows that African stock markets are affected by developments in the international markets. Hence, portfolio diversification opportunities exist in the African stock markets suggesting that investors should also consider investing in their African countries as they offer opportunities rather than considering investing in the international markets only.
\end{abstract}

Keywords: Stock Market Integration; Africa; South Africa; VAR; Portfolio Investment

\section{INTRODUCTION}

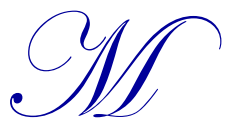

ost African stock markets are very small and still growing compared to world market standards. They are fragmented, lack economies of scale, and lack operational efficiency (Ntim, 2012). Being disjointed, African capital markets are illiquid and ranked last on the competitive global financial market scale. This poses a lot of risk to African economies, as the economic landscape is rapidly changing and globalisation is increasing. Financial theory suggests that integrated stock markets are more efficient as compared to segmented stock markets. Hence, any disparities between stock market indices pose good opportunities for international investors to diversify their portfolios and any interdependence between stock markets may reduce the possibility of diversification (Srikanth, 2012).

More so, financial integration is believed to be accelerated by the growing reliance of nations on savings from other nations and the shift in the leverage preference of companies from debt to equity finance. Stock market integration is also perceived to be beneficial; that is; it leads to well-developed markets and institutions, boosts liquidity, increases competitiveness, lowers costs and encourages information sharing across financial institutions, creates wide choices and innovations across institutions, and offers companies and consumers more financing opportunities. On the other hand, stock market linkages pose risks, such as contagion and disruptions in economic activity, as evidenced by the 1997 Asian contagion which started with Thailand and spread across bordering South East Asian countries and into Latin America.

Furthermore, international investment inflows and outflows can have a substantial influence on emerging market economies and their stock markets. That is, monetary policies in a domestic economy could be affected by the linkages between the local capital market and other markets within the sub-region and globally. Hence, improved integration might consequently have macroeconomic and monetary policy implications (Agyei-Ampomah, 
2011). Howbeit, according to Alagidede (2009) and Ntim, Opong, Danbolt and Dewotor (2011), African stock markets (excluding South Africa) are comparatively different from their developed counterparts and insignificant compared to other emerging markets despite the rapid development in the establishment of stock markets in Africa.

Thus, lack of integrated stock markets in Africa does not only affect the effectiveness of price discovery which depresses savings opportunities and investments and hinders economic progress but is an inimical practice in a globally integrated world. Having well-integrated stock markets in Africa is of great importance thereof. In this study, the main focus is to determine any long-run dynamic relationship between the Johannesburg Stock Exchange (JSE) and other selected stock markets in Africa.

Following the introduction, which is Section 1, Section 2 focuses on the overview of the development of the African stock markets, with special emphasis on the trends, development, functions, and characteristics of the markets; Section 3 focuses on the literature review, which focuses on the importance of integration. Section 4 focuses on the empirical framework, with emphasis on the formulation and estimation of the specified model, and Section 5 focuses on interpretation of results and conclusion.

\section{OVERVIEW OF THE AFRICAN STOCK MARKETS}

A stock market in a developing economy can be one of the main drivers of economic growth if it provides development finance by routing domestic savings and attracting foreign investment. However, in Africa, stock markets face intense challenges in terms of depth measured by market capitalization and listing (Allen, Otchere \& Senbet, 2010). The following section provides an overview of the development of stock markets in Africa. The emphasis is on the trends, development, functions, and characteristics of the markets.

\subsection{Development Of Stock Markets In Africa}

Some researchers (Yartey and Adjasi, 2007; Akinlo and Akinlo, 2009) have found a strong positive relationship between stock market development and economic growth in Africa. Of their findings, a $1 \%$ increase in liquidity could account for approximately $3.7 \%$ increase in African economic growth in the long run, and the authors further evidenced a short-run finance-led growth hypothesis for countries such as Egypt and South Africa. More so, the number of operating stock exchanges rose from eight in 1989 to twenty three in 2007, reaching a total market capitalisation of over \$2.1 trillion (Massa, 2009). Since 1995 there has been at least one African stock market in the top ten best-performing markets in the world. According to the Overseas Development Institute (ODI) research report by Massa (2009) in 2004, six African countries (Ghana, Uganda, Kenya, Egypt, Mauritius and Nigeria) were among the world's ten best-performing stock markets and in 2006, Malawi out-performed every other market in the world (Massa, 2009).

\subsection{African Stock Markets Capitalisation}

The emergence of these stock markets in the African continent provides important opportunities for integrating Africa into a global financial market for attracting global capital. Over the years, especially in the early twenty first century, there has been a sharp increase in initial public offerings (IPOs) which have allowed some businesses to raise sizeable amounts of capital. For example, the Lagos Stock Exchange in Nigeria raised approximately US\$4 billion since 2000 (Nkontchou, 2010). African stock markets have grown and have been improving in terms of market capitalisation. However, in 2008, market capitalisation dropped considerably for all African stock markets with countries such as Zimbabwe, Swaziland and Zambia, recording zero percent of GDP. South Africa, on the other hand, is the best performing stock market in Africa with a market capitalisation of 159\% of GDP in 2003 and a 179\% in 2008 amidst the financial crisis.

Although African stock markets have shown some improvements over the years, in terms of market performance and listings, among others, full stock market development is still at infancy compared to global standards. Surprisingly, even the most advanced stock markets are still immature. There are various bottlenecks affecting the growth and efficiency of African stock markets and amongst those bottlenecks is the lack of access to 
the banking sector to the private sector (Dahou, Omar \& Pfister, 2009). In a nutshell, African stock markets possess almost the same characteristics, with a few exceptions to the JSE and EGX, including:

- Weak regulatory framework: There is minimal or inadequate supervision by regulatory authorities.

- Lack of innovative financial instruments: Most trading occurs in only a few stocks which make up for a considerable part of the total market capitalisation. There are serious informational and disclosure deficiencies for other stocks apart from the actively traded ones.

- $\quad$ The African stock markets are dominated by a few large companies which represent a high proportion of total market capitalisation. Also, most of the stock markets, except for the JSE, EGX and, to a lesser extent, NSE, have limited or few listings.

- $\quad$ Markets are illiquid. There are large gaps between buy and sell orders, thus shares are rarely traded and business volume is too low.

- $\quad$ The stock markets lack operational efficiency.

- $\quad$ The stock markets are fragmented.

They also have the following infrastructural characteristics:

- Have diversified trading mechanisms (such as on-line trading; margin trading and short selling and borrowing)

- $\quad$ Unrestricted foreign participation in the stock markets

- $\quad$ Shorter settlement cycles and the availability of alternative markets (for instance, the derivatives market in South Africa).

\subsection{Liquidity Of African Stock Markets}

Stock market liquidity is measured by the ease with which investors can buy and sell securities at given prices. However, due to the difficulty in obtaining such statistical data, two alternative measures of stock market liquidity are used to investigate the rate to which African stock markets are liquid. The turnover ratio, which measures the market's overall trading activity relative to the size of the market, is used in conjunction with the total value of shares traded on the exchange scaled by GDP as the two alternate standard indicators for stock market liquidity. The former is measured by the total value of shares traded scaled by the total market capitalization and the latter measures the market's trading activity, relative to the size of the economy (Allen et. al., 2010).

Despite the growth of the African stock markets over the years, most of the African stock markets are still very illiquid, except for South Africa, Egypt and Zimbabwe. As shown in Figure 1, the total value of stocks traded, scaled by GDP, is very low, although, in general, the market performance has been improving. In countries such as Botswana, Zambia and Namibia, the value of stock traded is hardly more than $1 \%$ of GDP.

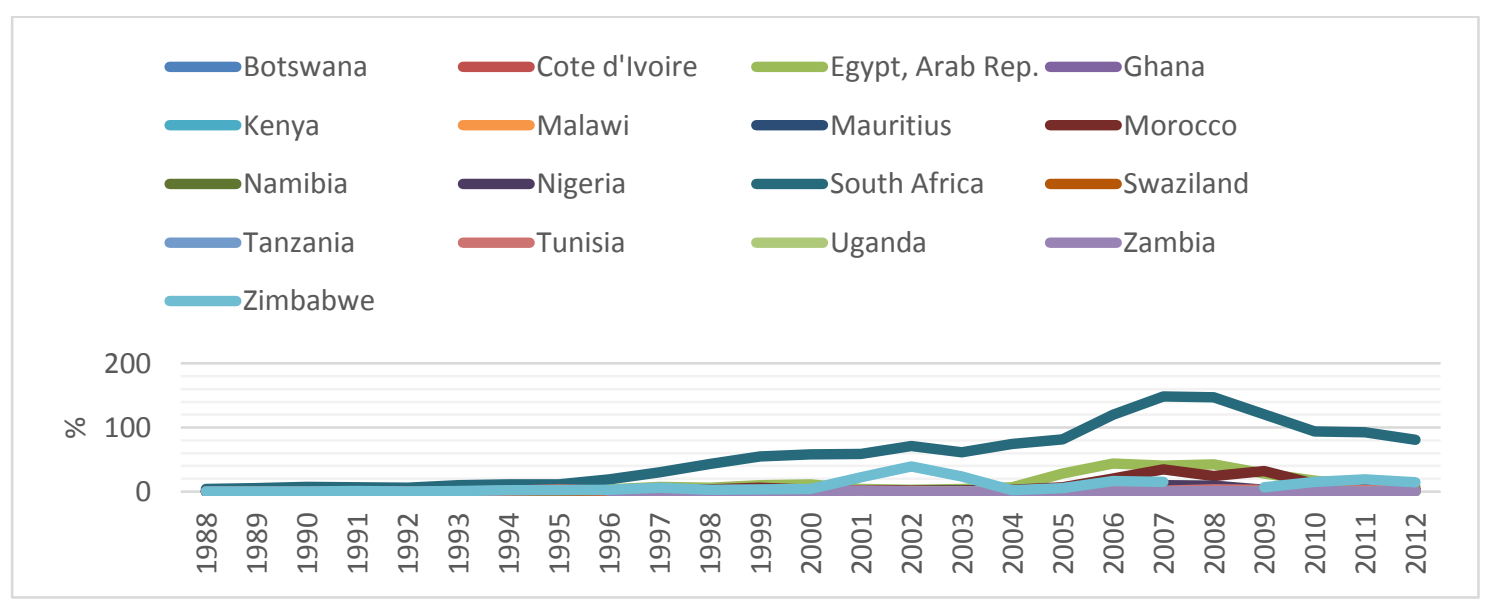

(Source: World Data Bank, 2013)

Figure 1: Africa Stock Markets - Stocks Traded, Total Value (\% of GDP) 
The same scenario is observed using the turnover ratio, reflecting minimal trading activity. Wellestablished stock markets (South Africa \& Egypt) exhibit high liquidity compared to other African stock markets as shown in Figure 2. In addition, most African stock markets, as discussed earlier, are faced with low liquidity due to the lack of innovativeness in securities traded. However, with the realisation that establishing a stock market only is not enough to sustain a profitable and healthy market, most policymakers in Africa are addressing the challenges faced by the markets.

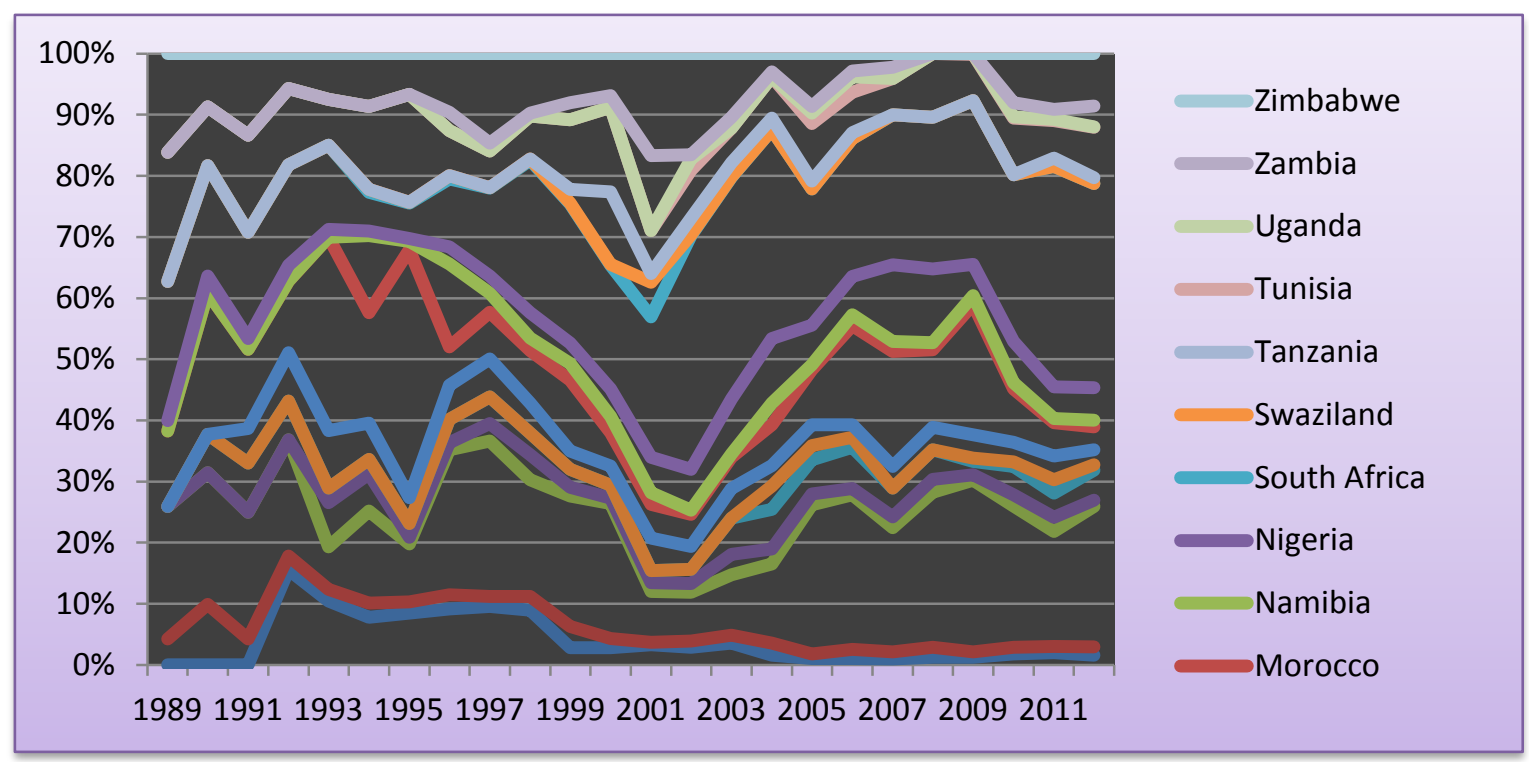

(Source: World Data Bank, 2013)

Figure 2: African Stock Markets - Stocks Traded, Turnover Ratio (\%)

Amongst the measures adopted in fostering depth and liquidity of African stock markets is the regional consolidation of markets (for instance, the establishment of a regional stock market housed in Abidjan, namely Bourse Regional des Valeurs Mobiliéres (BVRM)). The BVRM serves as an anchor for the Francophone countries of West Africa and other African regions are considering such initiatives (Allen et al., 2010) as well.

\subsection{Profitability Of African Stock Markets}

According to Allen et al. (2010:11), "the viability of African stock markets as investment opportunities depends on the extent to which they have the potential to improve risk-return trade-offs facing global investors". As a matter of fact, African equities represent a vastly underutilized option for international investors. These are growing markets that have provided attractive returns in the last several years and can achieve the goal of portfolio diversification as they offer a superior risk/return profile (through very attractive price-earnings ratios) that is not affected by trends in the more developed markets. For instance, the private investment activity for Africa increased by $136 \%$ in 2013 - to US\$ 3.2 billion, up from US\$ 1.46 billion in 2012 (Hlophe, Stokoe, Bunder, Rogers \& Date, 2014).

Hence, apart from the poor performance and the vast challenges faced by most African stock markets, they pose as a good investment opportunity for portfolio diversification for international investors. Also, smaller African markets have proved relatively immune to global tensions, hitting share values worldwide due to their lack of correlation with developed markets (Bunyi, 2003). This diverse characteristic of African equity markets therefore offers positive benefits in terms of risk diversification. 


\section{REVIEW OF RELEVANT LITERATURE}

A number of studies have been carried out to establish the link between stock markets. Of the available studies, Agyei-Ampomah (2011) and Srikanth and Aparna (2012) used descriptive statistics on monthly data for the period 1998-2009 to examine stock market integration for African stock markets and the Indian stock market. Obtained results differ. The former author concluded that African stock markets are segmented and far from being integrated and any integration thereof is not reflected in the stock markets, if there is any. The latter concluded that there is a substantial integration between India and international financial markets.

Moreover, some studies were conducted for different stock markets using the Johansen cointergration technique, daily and weekly data for the period 1995-2006 (Neame, 2002; Karim and Karim, 2008; Onour, 2009; Raj and Dhal, 2009). Neame and Raj and Dhal concluded that the GCC and India equity markets offer international investors portfolio diversification potential; that is, they are integrated with the rest of the world. However, whilst Karim and Karim (2008) found a direct link between US, Malaysia, China and Japan, Onour, (2009) found a nonlinear cointergration between Egypt, Morocco and Tunisia. Thus, the results show that emerging markets are not yet fully integrated and well-developed markets are integrated. These results concur with the ones based on monthly studies ranging from 1991 to 2011 (Darrat, Ekhal and Hakim, 2000; Jain and Bhanumurthy, 2005; Arouri and Jawadi, 2009; Adelebola and Dahalan, 2012).

Daily and weekly studies ranging from the period 1991-2004 based on the Granger causality technique provide varying conclusions. Wong, Agarwald and Du (2003) contest the findings made by Mukherjee and Mishra (2005). The former concluded that the Indian stock market is integrated with the world equity markets whilst the former denies any link between India and the world equity markets. However, Cerny (2004) found that US, London, Frankfurt, Paris, Warsaw and Prague markets react quickly to the information revealed in the prices of others; hence, they are integrated.

Ayuso and Blanco (1999) employed the VAR model on weekly data to assess if financial market integration increased during the nineties. Empirical results show that integration increased during this period. Using the same model, a study based on daily data conducted by Melle (2001) produced the same results as the study by Bartram, Taylor, and Wang (2006). Both these studies show that the introduction of a common currency accelerated the rate of integration in the European countries; hence, common currency is an ideal policy for stock market integration.

There are studies which have employed the GARCH model utilising daily data for the period 1994-2012. These studies include Fratzscher (2001), Batram, Taylor and Wang (2006), Wang and Moore (2008), Yoshida (2009), and Baumohl (2013). The majority of these studies concur with those conducted using weekly data. For instance, Berben and Jansen (2005) utilised weekly data for the period 1980-2003 and concluded that stock market integration advanced in the late 1980s and 1990s in Europe; that is, the stock markets from the developed nations prove to be integrated. More so, monthly studies provide the same results for different markets. Buttner and Hayo (2008), Johansson (2009), Guesmi (2011), Arouri (2012), and Berger and Pozzi (2012) conducted the studies within the range of 1970-2011. All the studies show that integration is increasing for the different stock markets. Other studies (Ntim, 2012; Onour, 2009) utilised daily data for the different African countries to determine why African stock markets should formally harmonise and to determine financial integration of North African stock markets, utilising the parametric and non-parametric variance ratios and Breitung (2001) rank test. The results from the study conducted by Ntim (2012) suggest that there is a weak form of information efficiency, and the author concluded that formal harmonisation may improve information efficiency. Also, results from Onour (2009) provided evidence of multivariate and bivariate non-linear cointegration between the three North African stock markets (Egypt, Morocco and Tunisia).

However, in a study conducted by Alagidede (2008) on the implications for portfolio diversification and international risk-sharing for African stock market integration, the results suggest that African stock markets share a weak trend with the rest of the world and there is a unidirectional causality between South Africa and emerging markets. The study covered the period 1997-2008 (monthly data) for ten countries (South Africa, Egypt, Nigeria, Kenya, Brazil, Mexico, India, United States of America, Japan and the United Kingdom) and utilised both the 
Johansen cointegration test and granger causality test using the VAR model. The results of the study concur with the one done by Adebola \& Dahalan (2012) concerning the level of interaction between African stock markets.

Tam and Tam (2012) conducted a study on re-thinking stock market integration - globalisation, valuation and convergence using monthly data for the period 1973-2011. By using a unified framework synthesizing the stock valuation model and convergence hypothesis, results show that integration varies within different time periods for the 51 countries studied across the globe. This study somewhat concurs with the one done by Babetskii, Komarek and Komarkova (2007). In the latter case, weekly data from 1995 to 2006 and the standard and rolling correlation analysis were used to determine the level of integration for Czech Republic, Hungary, Poland and Slovakia. Results revealed that the stock markets are integrated at both national and sectorial levels.

The review of literature indicates that studies focusing on Africa are still limited and provide scanty information on the rate of integration in the region. Well-integrated markets are arguably necessary for portfolio diversification and raising finance. Thus, this study seeks to add to the debate regarding integration of the stock markets in Africa.

\section{DATA AND EMPERICAL FRAMEWORK}

Data used in the study were obtained from Bloomberg. It constitutes samples of five African stock markets (South Africa, Botswana, Namibia, Mauritius and Nigeria) and Germany (DAX index), Japan (NIKKEI 225 index) and the USA's S\&P 500 index (to represent the world stock markets). Other African and world stock markets are not included in the sample due to the unavailability of data. The markets in the sample have well-reported and available data. This study utilises monthly data to avoid the possible effects of autocorrelation in volatility and to circumvent the problem of non-synchronous trading for the period February 2000 to September 2008. Further, the study period was chosen attributable to availability of data. The All-Share Index (ASI) is used as the proxy for the South African stock market (JSE). The BGS-MDC Index, SEMDEX Index, NSX overall Index and NGSE Index are used for Botswana, Mauritius, Namibia and Nigeria, respectively.

\subsection{Model}

Financial theory asserts that stock market integration is a consequence of the relationship between different stock markets and/or movements of portfolios between them. Two models are estimated in this study - the first one focuses on the relationship between African stock markets and the second model seeks to examine the extent to which African stock markets are integrated into the world stock markets.

\subsubsection{Model 1}

The model used in this study was adopted from Adebola and Dahalan (2012) to investigate the relationship between stock indices across selected African stock markets based on the law of one price theory. Stock market indices are used as a proxy for stock market performance since it is an indicator of the stock market performance (Chuang, Ouang \& Lo, 2010; Kao \& Tate, 2001; Abraham, 2009). In other words, indices measure the overall stock market behaviour and therefore represent the entire market and set the broad outline of market movements. It captures major economic units; that is, it acts as a status report on the general performance of the economy and is a useful tool for evaluating investors' portfolios.

The study utilises the VAR model in establishing the extent to which stock markets in Africa are integrated. Assuming that $X_{t}$ is the nx1 vector of logged variables, the intra-impulse transmission process of which is to be captured by the study, the dimension of $\mathrm{X}_{\mathrm{t}}$ (that is $\mathrm{n}$ ) is 5 , given the five variables of the analysis. The VAR model for the study is discussed below. Using matrix algebra notations, a 5-variable structural dynamic economic model for the study can be stated as: 
$\mathrm{BX}_{\mathrm{t}}=\mu+\Gamma \mathrm{X}_{\mathrm{t}^{-1}}+\varepsilon_{\mathrm{t}}$

where $B$ is the matrix of variable coefficients

$\mathrm{X}_{\mathrm{t}}$ is the $5 \times 1$ vector of observations at time $\mathrm{t}$ of the variables of the study; that is, vector $\mathrm{X}$ is defined as $\mathrm{X}_{\mathrm{t}}=\left(\log S_{t}\right.$, $\log B_{t}, \log M_{t}, \log N a_{t}, \log N i_{t}$,

where $\log S_{t}$ is the South African stock market index, $\log B_{t}$ is the Botswana stock market index, $\log M_{t}$ is the Mauritius stock market index, $\log N a_{t}$ is the Namibian stock market index, and $\log N i_{t}$ is the Nigerian stock market index.

\subsubsection{Model 2}

Intuitively, it is of paramount importance to address empirically the question of whether African stock markets are completely segmented. To investigate further the dynamic relationship between African stock markets and the rest of the world, a VAR in first difference for the non-cointegrated markets is estimated. The model is advantageous in that "it estimates the dependence among markets and allows shocking a particular market and analysing how shocks perpetuate themselves through impulse responses" (Alagidede, 2008:46).

The study utilises the USA (S\&P 500) index as the proxy for world stock markets and further incorporates the Japan (NIKKEI 225 index) and Germany (Deutscher Aktien index/DAX index) stock markets to provide a comprehensive argument for the world markets due to their sizes. In a broad-spectrum, a $k t h$ order VAR in first difference for a $2 \mathrm{x} 1$ vector of jointly determined (endogenous) variables $\mathrm{X}_{\mathrm{t}}$ is presented as follows:

$\Delta X_{t}=\mu+\sum_{i=1}^{k} \prod_{i} \Delta X_{\mathrm{t}-\mathrm{i}}+\varepsilon_{t}$

where $\varepsilon_{t}$, the residual factor, is said to be the innovation shock in $\mathrm{X}$ that cannot be predicted from past values of variables in the system. The corresponding MAR (moving average representation) is derived from the following equation (either by successive substitution or polynomial lag division):

$\Delta X_{\mathrm{t}}=\Pi^{-1}(B) \varepsilon_{t}=\Psi(B) \varepsilon_{t}=\varepsilon_{t}+\sum_{i=0}^{\infty} \Psi_{\mathrm{i}} \varepsilon_{t-i}$

where $\Psi_{\mathrm{i}}=\sum_{j=1}^{i} \Pi_{j} \Psi_{i-j}$ and $\Psi_{0}=I_{n}$

In the above model, no distinction is made between endogenous and exogenous variables.

$\Psi_{\mathrm{i}}$ represents the matrices that are the dynamic multipliers of the system; that is, they represent the model's response to a unit shock in each of the variables. According to Sims (1980), it is more informative to analyse the system's reaction to typical random shocks by tracing out the system's MAR rather than to continue with the complicated cross-equation feedbacks involved in the Autoregressive representation (AR). Thus, while the estimated coefficients in the VAR provide little insight as to the dynamic interactions amongst the series, the MAR is the best representative because it presents information equivalent to that contained in the original estimates and it allows the tracing of the time path of the various shocks on the return series (Alagidede, 2008).

A positive relationship is expected amongst the five African stock markets. Moreover a further positive relationship between African stock markets and the world stock markets is also expected.

\subsection{Estimation Technique}

Prior to estimating the VAR model to be used to determine stock market integration between the JSE and the selected African stock markets, the time series properties of the stock indices will be analysed carefully through the Augmented Dickey Fuller (ADF) and the Phillips Peron (PP) tests. These two methods are not discussed here as they are well-documented in the literature. The two methods will be used in order to get robust results. 


\subsubsection{Johansen Cointergration Approach}

Traditionally, measuring integration is usually done by applying correlation and cointegration tests. Howbeit, a study by Pukthuanthong and Roll (2009) proves that correlation across markets is a poor measure of integration, as perfectly integrated markets can reveal weak correlation. Intuitively, any existence of cointegration in a speculative market has been argued by early literature (for instance, Engle and Granger, 1987) to imply violation of market efficiency since past prices could be used to improve current price forecasts. This phenomenon has since changed and the existence of cointegration relationship between stock prices is believed not to necessarily imply market inefficiency (Adelebola \& Dahalan, 2012). Consequently, the Johansen cointegration test, which is a Vector autoregressive (VAR) framework, provides a unified approach for the estimation of the multivariate cointegration system based on the error correction mechanism of the VAR $(\kappa)$ model.

Assuming $X_{t}$ is a set of I (1) variables consisting of $\mathrm{n}$ stock indexes, the VAR $(\kappa)$ model is specified as:

$\log X_{t}=\mu+\beta_{1} \log X_{t-1}+\beta_{2} \log X_{t-2}+\beta_{\kappa} \log X_{t-\kappa}+\varepsilon_{t}$

where

$\beta_{\kappa}$ is an $\mathrm{n} \mathrm{x}$ coefficient matrix

$t=1,2,3 \ldots \mathrm{T}$

$\varepsilon_{t}$ is an error term

To estimate the Johansen cointegration test, Equation (3) may be transformed into an error correction model as follows:

$\Delta \log X_{t}=\mu+\sum_{i=1}^{k=1} \Gamma_{\mathrm{i}} \Delta \log X_{t-i}+\Pi \log X_{t-\kappa}+\varepsilon_{t}$

where

$\Delta$ is the first difference operator

$\Gamma_{i}$ is an $\mathrm{n} \times \mathrm{n}$ coefficient matrix defined as $\Gamma_{i}=-\left(\mathrm{I}-\beta_{1}-\beta_{i}\right)$, representing the short-run dynamics, $\Pi$ is an $\mathrm{n} \times \mathrm{n}$ matric defined as $\Pi=-\left(\mathrm{I}-\beta_{1}-\beta_{\kappa}\right)$, representing the long-run dynamics, and $\mathrm{I}$ is an identity matrix whose rank determines the number of distinct cointergrating vectors.

$\varepsilon_{t}$ is the diagonal matrix of structural innovations that has zero means, constant variance and are individually serially correlated. In the event that there is cointegration, a Vector Error Correction model is estimated; however, if there is no cointegration, a VAR model in first difference is estimated.

\subsubsection{Granger Causality}

In an integrated market, stock market performance is assumed to be affected by the performance of another. The efficient market hypothesis suggests that stock market prices reflect all the available information. Thus, in a fully integrated market, all the information in one country's stock market is translated into the other stock market's stock price of the same portfolio. In other words, past changes in one country's stock price should cause the change in another country's stock price.

Defined by Granger (1969), the Granger causality test determines any correlation between the current value of one variable and the past values of others. It assumes that "time series involved in the analysis are stationery and are sensitive to lag length selection, hence the need for conducting stationarity tests and determining the proper lag length before carrying out the causality test" (Brooks, 2008:298). Thus, the test seeks to answer the question, "Do 
changes in $X_{1}$ (stock market 1) cause changes in $X_{2}$ (stock market 2)?" Hence, a granger causality test "determines the correlation between the current value of one variable and the past values of others" (Brooks, 2008: 298).

This phenomenon is presented in the following linear model:

$X_{t}=\alpha+\propto X_{t-1}+\propto X_{t-\kappa}+\dot{Z}_{t-1} \gamma_{1}+\dot{Z}_{t-\kappa} \gamma_{\kappa}+e_{t}$

where

$X_{t}$ and $Z_{t}$ are vectors for the different African stock market indices.

$e_{t}$ is the error term.

In Equation (5), $Z_{t}$ does not granger cause $X_{t}$ if $H_{0}:=\gamma_{1}=\gamma_{2}=\gamma_{\kappa}=0$. That is, the null hypothesis $H_{0}$, that one stock market does not granger cause another stock market, is tested using the F-test.

The linear equation can be expressed in a VAR model as follows:

$\left[\begin{array}{l}Y_{t} \\ Z_{t}\end{array}\right]=\sum_{i=1}^{p}\left[\begin{array}{ll}a_{11 i} & a_{12 i} \\ a_{21 i} & a_{22 i}\end{array}\right]\left[\begin{array}{l}Y_{t-1} \\ Z_{t-1}\end{array}\right]+\mu_{t}$

In the event that the variables are $\mathrm{I}(0)$, a test that $Y_{t}$ granger causes $Z_{t}$ is tested as:

$a_{21 i}=0$ for $i=1,2,3 \ldots \ldots \ldots .$.

However, in the case for which the variables are I(1), the above VAR granger causality model can be rewritten in a VECM format as:

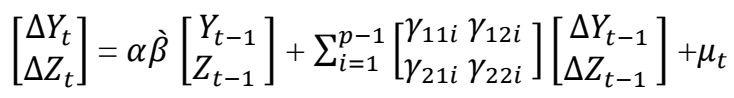

where $\alpha \grave{\beta}$ can be expressed as:

$\alpha \grave{\beta}=\left[\begin{array}{l}\alpha_{1} \\ \alpha_{2}\end{array}\right]\left[\beta_{1} \beta_{2}\right]=\left[\begin{array}{ll}\alpha_{1} \beta_{1} & \alpha_{1} \beta_{2} \\ \alpha_{2} \beta_{1} & \alpha_{2} \beta_{2}\end{array}\right]$

By replacing $\alpha \grave{\beta}$ by the latter expression to the former I(1) granger causality model, the granger causality tests the following hypotheses:

$\gamma_{21 i}=0$, for $i=1,2,3 \ldots \ldots p-1 ;$ and $\alpha_{2} \beta_{1}=0$.

The causality test is performed to identify the existence and nature of the causality relationship between the variables. This is appropriate to identify relationships between variables because multiple relationships may cause simultaneity, especially if the variables involved in the model are more than two.

\section{EMPIRICAL ANALYSIS AND INTERPRETATION OF RESULTS}

The statistical results in Tables 1 and 2 refer to the unit root test based on the Augmented Dickey Fuller and the Phillips Peron tests. They provide some preliminary statistics on all the variables in the explained model 1 South Africa (All Share Index), Botswana (All Company Index), Mauritius (SEMDEX Index), Namibia (NSX overall Index) and Nigeria (NGSE Index) - and model 2 - USA (S\&P 500 index), Japan (NIKKEI 225 index) and Germany (DAX index). 
Table 1: Unit Root Results (Level Series)

\begin{tabular}{lccc|ccc}
\hline & \multicolumn{3}{c}{ ADF } & & PP \\
\hline Variables & Intercept & $\begin{array}{c}\text { Trend and } \\
\text { Intercept }\end{array}$ & None & Intercept & $\begin{array}{c}\text { Trend and } \\
\text { Intercept }\end{array}$ & None \\
\hline $\log S_{t}$ & -0.505756 & -1.686155 & 1.949575 & -0.511318 & -1.754834 & 1.941334 \\
$\log B_{t}$ & -0.474577 & -1.974616 & 2.084729 & -0.497017 & -1.836493 & 2.436586 \\
$\log M_{t}$ & 1.241856 & -2.682062 & 3.504807 & 0.779603 & -2.609173 & 2.618034 \\
$\log N a_{t}$ & -0.120734 & -1.313576 & 5.871358 & -0.190162 & -1.561084 & 5.016472 \\
$\log N i_{t}$ & -1.389666 & -2.423082 & 2.371769 & -1.297434 & -2.118007 & 2.859545 \\
$\log \mathrm{J}_{t}$ & -1.935782 & -2.383943 & -1.076698 & -2.031278 & -2.394358 & -0.944333 \\
$\log \mathrm{G}_{t}$ & -1.469146 & -1.876609 & -0.445201 & -1.482076 & -1.883030 & -0.445201 \\
$\log \mathrm{USA}_{t}$ & -1.438498 & -1.822575 & -0.235871 & -1.445705 & -1.797865 & -0.241670 \\
\hline
\end{tabular}

$*, * *, * * *$ imply $10 \%, 5 \%$ and $1 \%$ significance levels, respectively.

Table 2: Unit Root Results (First Difference Level)

\begin{tabular}{|c|c|c|c|c|c|c|}
\hline & \multicolumn{3}{|c|}{ ADF } & \multicolumn{3}{|c|}{$\mathbf{P P}$} \\
\hline Variables & Intercept & $\begin{array}{l}\text { Trend and } \\
\text { Intercept }\end{array}$ & None & Intercept & $\begin{array}{l}\text { Trend and } \\
\text { Intercept }\end{array}$ & None \\
\hline $\log S_{t}$ & $-9.608737 * * *$ & $-9.544905^{* * *}$ & $-9.289750 * * *$ & $-9.613040 * * *$ & $-9.549643 * * *$ & $-9.403715^{* * *}$ \\
\hline $\log B_{t}$ & $-4.991868 * * *$ & $-4.970082 * * *$ & $-4.439450 * * *$ & $-5.053308 * * *$ & $-5.033203 * * *$ & $-4.435629 * * *$ \\
\hline $\log M_{t}$ & $-7.772212 * * *$ & $-7.989486^{* * *}$ & $-7.161651 * * *$ & $-7.956173 * * *$ & $-8.038536 * * *$ & $-7.596479 * * *$ \\
\hline $\log N a_{t}$ & $-9.523553 * * *$ & $-9.501240 * * *$ & $-3.077530 * * *$ & $-9.630150 * * *$ & $-9.606322 * * *$ & $-8.509077 * * *$ \\
\hline $\log N i_{t}$ & $-7.326732 * * *$ & $-7.368620 * * *$ & $-6.725304 * * *$ & $-7.337195 * * *$ & $-7.374934 * * *$ & $-6.728552 * * *$ \\
\hline $\log _{t}$ & $-8.793345 * * *$ & $-8.835472 * * *$ & $-8.743679 * * *$ & $-8.951839 * * *$ & $-8.912320 * * *$ & $-8.904424 * * *$ \\
\hline $\log \mathrm{G}_{t}$ & $-9.677479 * * *$ & $-9.796282 * * *$ & $-9.712358 * * *$ & $-9.677479 * * *$ & $-9.800827 * * *$ & $-9.712358 * * *$ \\
\hline $\log \mathrm{USA}_{t}$ & $-9.705086 * * *$ & $-9.716609 * * *$ & $-9.751643 * * *$ & $-9.698032 * * *$ & $-9.709402 * * *$ & $-9.746956 * * *$ \\
\hline
\end{tabular}

(Source: Author's Computation)

$*, * *, * * *$ imply $10 \%, 5 \%$ and $1 \%$ significance levels, respectively.

The time series properties of the data show that all variables are non-stationary at level series as reported by both the ADF and the PP. However, at first differences all variables are stationary. Therefore, the authors proceed to test for cointegration among the variables in order to determine any linkages between African stock markets. The cointegration analysis helps to explore the stochastic trends in the series based on the Johansen (1995) cointegration test. Innately, in the event that financial markets share a common trend, then there will be no long-term gains for international diversification. An important component in performing a VAR is the proper determination of the number of lags to be used. Hence prior to conducting the cointegration test, the lag length was determined.

\subsection{Lag Length Selection}

Table 3 shows the results of the lag length selection test. The study used a lag of one, as chosen by the Schwarz Information Criterion (SIC) and Hannan-Quinn criterion (HQIC). Adding more lags increases the penalty for the loss of degrees of freedom (Brooks, 2008). Hence, the above-mentioned criterions concur that the maximum lag length for the six endogenous variables is one. This implies that the VAR for this study is estimated using the lag length of one for each endogenous variable. 
Table 3: VAR Lag Order Selection

\begin{tabular}{ccccccc}
\hline Lag & LogL & LR & FPE & AIC & SC & HQ \\
\hline 0 & 231.6143 & NA & $3.66 \mathrm{e}-10$ & -4.700297 & -4.540026 & -4.635513 \\
1 & 996.7836 & $1418.751^{*}$ & $9.27 \mathrm{e}-17$ & -19.89132 & $-18.76942^{*}$ & $-19.43783^{*}$ \\
2 & 1038.233 & 71.67225 & $8.35 \mathrm{e}-17^{*}$ & $-20.00485^{*}$ & -17.92131 & -19.16265 \\
3 & 1052.604 & 23.05423 & $1.34 \mathrm{e}-16$ & -19.55425 & -16.50909 & -18.32335 \\
4 & 1072.191 & 28.97308 & $1.96 \mathrm{e}-16$ & -19.21232 & -15.20553 & -17.59271 \\
5 & 1110.299 & 51.60397 & $2.02 \mathrm{e}-16$ & -19.25623 & -14.28781 & -17.24791 \\
6 & 1137.013 & 32.83592 & $2.73 \mathrm{e}-16$ & -19.06277 & -13.13272 & -16.66575 \\
7 & 1176.802 & 43.93345 & $2.95 \mathrm{e}-16$ & -19.14170 & -12.25002 & -16.35597 \\
8 & 1232.745 & 54.77786 & $2.44 \mathrm{e}-16$ & -19.55719 & -11.70387 & -16.38275 \\
\hline
\end{tabular}

* indicates lag order selected by the criterion

LR: sequential modified LR test statistic (each test at 5\% level)

FPE: Final prediction error

AIC: Akaike information criterion

SC: Schwarz information criterion

HQ: Hannan-Quinn information criterion (Source: Author's Computation).

\subsection{Co-Integration Results}

Having selected the ideal lag for the model, the next step was to conduct the Johansen cointegration test. Prior to testing for cointegration relationships, the authors first determined whether deterministic components, such as constant, time trend and dummy variables, should be included in the model. Thus, using the general to specific approach, a linear deterministic trend (at intercept, no trend in CE and VAR) was chosen as the most appropriate model for the cointegration space. Table 4 tabulates the co-integration test results for stationary variables using trace and max-eigenvalue methods and the computations indicate the presence of a single cointegration equation at none at $5 \%$ level of significance.

However, to a greater extent, the law of one price does not hold in that there are potential gains from portfolio diversification among the African stock markets since there is only a single cointegration equation. With the presence of cointegration, instead of estimating a VAR at first difference, a VECM was estimated to determine the short-run dynamics of the series.

Table 4: Johansen-Julius Cointegration Test Results

\begin{tabular}{|c|c|c|c|c|c|c|c|c|}
\hline Model & $\begin{array}{c}\text { Null } \\
\text { Hypothesis }\end{array}$ & $\begin{array}{c}\text { Statistical } \\
\text { Trace }\end{array}$ & $\begin{array}{c}\text { Critical Value } \\
(5 \%)\end{array}$ & $\begin{array}{l}\text { Maximum Eigen } \\
\text { Statistical Trace }\end{array}$ & $\begin{array}{c}\text { Critical } \\
\text { Value }(5 \%)\end{array}$ & Variable & $\begin{array}{c}\text { Long-term } \\
\text { Coefficient } \\
\text { Elasticity }\end{array}$ & Results \\
\hline \multirow{7}{*}{$\begin{array}{c}\text { Lag } \\
\text { Length }=1^{\#}\end{array}$} & $\mathrm{r} \leq 0$ & $112.7556^{* *}$ & 103.8473 & $47.87738 * *$ & 40.95680 & $\log (\mathrm{SA})$ & 1.000000 & \multirow{7}{*}{$\begin{array}{c}\text { Statistical } \\
\text { Trace showed } \\
\text { a 1- way } \\
\text { cointegration }\end{array}$} \\
\hline & $\mathrm{r} \leq 1$ & 74.87823 & 76.97277 & 25.35620 & 34.80587 & Log(Botswana) & -1.148727 & \\
\hline & $r \leq 2$ & 49.52203 & 54.07904 & 21.23420 & 28.58808 & Log(Mauritius) & 0.080549 & \\
\hline & $\mathrm{r} \leq 3$ & 28.28783 & 35.19275 & 13.62097 & 22.29962 & Log(Namibia) & 0.333255 & \\
\hline & $r \leq 4$ & 14.66686 & 20.26184 & 9.524351 & 15.89210 & Log(Nigeria) & -0.416785 & \\
\hline & \multirow[t]{2}{*}{$\mathrm{R} \leq 5$} & 5.142510 & 9.164546 & 5.142510 & 9.164546 & Dum & 0.982375 & \\
\hline & & & & & & $\mathrm{C}$ & 1.166151 & \\
\hline
\end{tabular}

(Source: Author's Computation)

$*, * *, * * *$ imply $10 \%, 5 \%$ and $1 \%$ significance levels, respectively.

\subsection{Diagnostic Checks}

The multivariate extensions of the residual test were applied in this study and are briefly discussed. After the estimation of the model using Eviews 7.0, an AR Roots test was used to test the stability of the model. The AR Roots (Figure 3) show that the VAR model is stationary because all the roots of the characteristic AR polynomial have absolute values of less than one which lie inside the unit circle indicating that the model is stable and can therefore be used in the analysis. 
Inverse Roots of AR Characteristic Polynomial

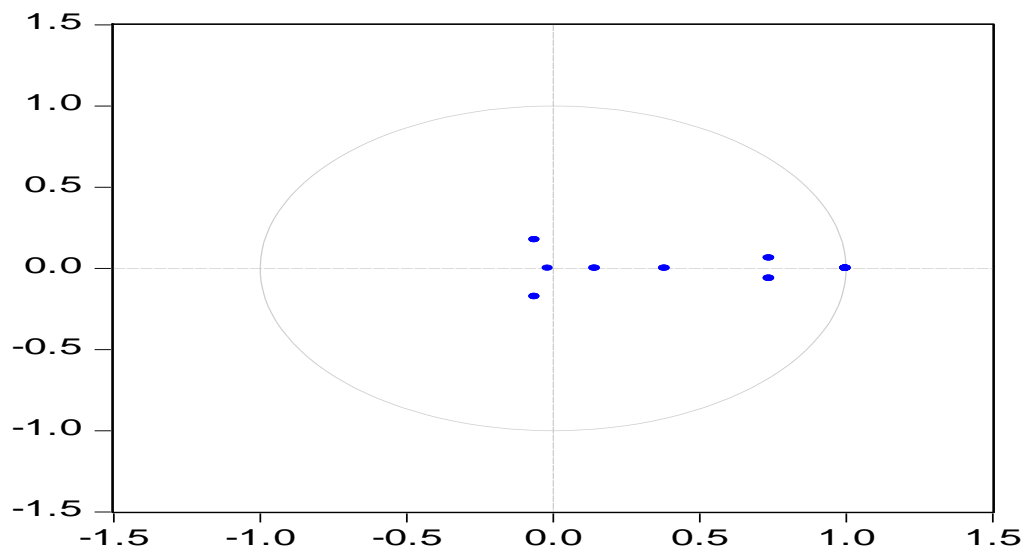

(Source: Author's Computation)

Figure 3: AR Roots Graph

\subsection{Granger Causality Results}

The main purpose of the research is to establish the relationship between the five African stock markets. A VAR Granger causality/Wald test was estimated and results are summarised in Table 5. In examining the existence of causality, it is observed that the past values of stock markets, such as JSE and NSE, affect movements or granger causes small markets. This is consistent with Adebola and Dahalan (2012). However, unlike with the variance and impulse response results, there are no causal links between JSE and BSE. In general, the evidenced causation is towards small markets, such as BSE, NSE and SEM, signalling a relationship between big and small markets but lack of relationship between big markets.

Table 5: VAR Granger Causality/Block Exogeneity Wald Test Results

\begin{tabular}{lccccccc}
\hline \multirow{2}{*}{ Variables } & \multicolumn{7}{c}{ Excluded } \\
\cline { 2 - 7 } & D(LSA) & D(LBotswana) & D(LMauritius) & D(LNamibia) & D(LNigeria) & D(Dum) & All \\
\hline D(LSA) & - & 2.046425 & 0.007446 & 0.015304 & 0.142886 & 4.855308 & 0.3082 \\
D(LBotswana) & 0.014164 & & 0.036065 & 0.000786 & 1.097007 & 0.142245 & 0.9182 \\
D(LMauritius) & $3.784468^{*}$ & 2.688929 & & 0.808890 & $5.730464^{* *}$ & $3.633585^{*}$ & $0.0064^{* * *}$ \\
D(LNamibia) & 0.128776 & 0.023724 & 0.537480 & & 1.219885 & 0.273574 & 1.913947 \\
D(LNigeria) & 0.180858 & 0.338221 & 0.007317 & 0.361376 & & $3.024835^{*}$ & 3.713975 \\
D(Dum) & 0.696119 & 2.196919 & 0.890849 & 1.195245 & 1.011880 & - & 5.521386 \\
\hline
\end{tabular}

(Source: Author's Computation)

$*$, **, *** imply $10 \%, 5 \%$ and $1 \%$ significance levels, respectively.

\subsection{Impulse Response Results}

The impulse response function recognizes the effect of a one standard deviation shock in one stock exchange to one of the innovations on current and future values of other stock exchange. An estimate was made of the impulse response functions of the different stock markets considered to innovations in each one of the other markets. Appendix 1 shows the graphs that represent the impulse response of each country to shocks in each one of the markets.

Observed results show that a one standard deviation shock to JSE has a positive impact to JSE. On the same note, standard deviation shocks to the BSE have a positive impact on the JSE, which is consistent with results of Adebola and Dahalan (2012) possibly due to the rapid alignment of the two stock markets in terms of dual listings and the move toward total standardisation of the regulation systems (Mlambo \& Biekpe, 2007). More so, a cholesky one standard deviation innovation to NSE, SEM and NSX insignificantly impacts on the JSE. A dummy variable was included in the estimation to take into account the period prior to the crisis (2008). Empirical results show the South African equity market did not respond instantaneously to the shock. In the same vein, the BSE responds 
positively to its own shocks and standard deviation shocks to the South African and Nigerian stock markets. The BSE market negatively responds to Namibian stock market and almost insignificant to standard deviation shocks to SEM.

Also, a one standard deviation shock to the NSX, BSE, and SEM impresses positively on SEM. Howbeit, a negative response to the shocks applied to the JSE is evidenced in the impulse response results. Arbitrage opportunities exist between the two markets; that is, the markets are still segmented. These results correspond with the results of Yartey and Adjasi (2007), Alagidede (2008), Agyei-Ampomah (2011), and Ntim (2012). The Namibian stock market responds trivially to shocks applied to SEM and NSE and positively to those applied to the BSE. Other portfolio diversification opportunities are shown in the response of NSX to shocks from the JSE. NSE responds positively to shocks from NSE, SEM and BSE and negatively to shocks applied to NSX. When standard deviation shocks are applied to the JSE, the NSE insignificantly responds.

As evidenced in the Johansen test results, there exists portfolio diversification opportunities within African stock markets. However, in the short run, as indicated by the impulse response, results reveal a certain degree of the operation of the law of one price for small African stock markets, mainly because most of the small African stock markets are adopting operational skills from the better developed African stock markets. Overall, as evidenced by Alagidede (2008), there is little feedback between African stock markets.

\subsection{Variance Decomposition Results}

Variance decomposition offers information about the relative importance of each random innovation in affecting the variation of the variables in the VAR; that is, it separates the variation in an endogenous variable into the component shocks to the VAR. Acquired results in Appendix 2 indicate some results from the response functions. The percentage variance of JSE, due to random innovations to BSE, is ten percent and insignificantly less than one percent for the rest of the markets (i.e., SEM, NSX, NSE). Thus, there is some considerable relationship between the JSE and the BSE. These results are consistent with the impulse response discussed in the previous section. As argued by Mlambo and Biekpe (2007), most of the listed companies in BSE are dual listed with the JSE and most of the trading occurs in the JSE instead of the BSE. In addition, variance decomposition results show that random innovations to JSE have a considerable impact (that is, $32 \%$ for the period considered) to BSE, which is more than the $31 \%$ of its own random innovations. In other words, there is a relationship between JSE and BSE as observed in the impulse response results.

The results also suggest that there is a relationship between NSX and NSE. Also, the BSE surprisingly seems to have a significant relationship with the other African stock markets. This is understandable as the market is still very small and is desperately trying to link itself with other stock markets in order to gain from them. Moreover, the evidence for the dummy variable shows that the JSE, being well-established and highly performing stock market and integrated to the world markets, is the only market that responds to the 2008 crisis. This further supports the fact that small African stock markets, to a larger extent, are not affected by world events, unlike bigger markets. However, the rate of integration is still very small and insignificant.

\section{7 Are African Stock Markets Related To The World?}

Prior to determining any relationship between African stock markets and the world stock markets, the time series properties were estimated using the ADF and PP tests. The results are tabulated in Tables 1 and 2 and they reveal that the time series are I (1). Using the same lag length of one, the long-run relationship between the African stock markets and the world stock markets is estimated using the Johansen cointegration test.

Based on Johansen and Juselius cointegration test (results shown in Table 6), the first normalized cointegrated vector (LSA) variable using lag period proposed by Schwartz information criterion (SIC) indicate two cointegrating equations at $5 \%$ level for both the $\lambda_{\text {trace }}$ and $\lambda_{\max }$ values. 
Table 6: Johansen-Julius Cointegration Test Results (World and African Stock Markets)

\begin{tabular}{|c|c|c|c|c|c|c|c|c|}
\hline Model & $\begin{array}{c}\text { Null } \\
\text { Hypothesis }\end{array}$ & $\begin{array}{l}\text { Statistical } \\
\text { Trace }\end{array}$ & $\begin{array}{c}\text { Critical Value } \\
(5 \%)\end{array}$ & $\begin{array}{l}\text { Maximum Eigen } \\
\text { Statistical Trace }\end{array}$ & $\begin{array}{c}\text { Critical Value } \\
(5 \%)\end{array}$ & Variable & $\begin{array}{c}\text { Long-term } \\
\text { Coefficient } \\
\text { Elasticity } \\
\end{array}$ & Results \\
\hline \multirow{10}{*}{$\begin{array}{l}\text { Lag } \\
\text { Length } \\
=1^{\#}\end{array}$} & $\mathrm{r} \leq 0$ & $271.0225^{* * *}$ & 208.4374 & $65.35212 * *$ & 59.24000 & $\log (\mathrm{SA})$ & 1.000000 & \multirow{10}{*}{$\begin{array}{c}\text { Statistical Trace } \\
\text { showed a 2- way } \\
\text { cointegration }\end{array}$} \\
\hline & $r \leq 1$ & $205.6704 * *$ & 169.5991 & $55.70347 * *$ & 53.18784 & $\log ($ Botswana $)$ & 0.149236 & \\
\hline & $\mathrm{r} \leq 2$ & 129.9669 & 134.6780 & 41.01934 & 47.07897 & Log(Mauritius) & -1.067414 & \\
\hline & $\mathrm{r} \leq 3$ & 102.9476 & 103.8473 & 29.62305 & 40.95680 & Log(Namibia) & -0.515862 & \\
\hline & $\mathrm{r} \leq 4$ & 75.32454 & 76.97277 & 24.57638 & 34.80587 & $\log ($ Nigeria $)$ & 0.241509 & \\
\hline & $\mathrm{r} \leq 5$ & 54.74816 & 54.87904 & 22.13387 & 28.58808 & Dum & 0.502110 & \\
\hline & $r \leq 6$ & 32.61429 & 35.19275 & 16.71492 & 22.29962 & $\log$ (Germany) & -2.399383 & \\
\hline & $\mathrm{r} \leq 7$ & 15.89937 & 20.26184 & 10.33445 & 15.89210 & $\log ($ Japan $)$ & -0.468921 & \\
\hline & \multirow[t]{2}{*}{$\mathrm{r} \leq 8$} & 5.564917 & 9.164546 & 5.564917 & 9.164546 & $\log ($ USA) & 5.086750 & \\
\hline & & & & & & $\mathrm{C}$ & -14.87276 & \\
\hline
\end{tabular}

(Source: Author's Computation)

$*, * *, * * *$ imply $10 \%, 5 \%$ and $1 \%$ significance levels, respectively.

Having established that there are two cointegrating equations in the series, the cointegration relationship can be re-expressed as depicted in Table 7. Only the relationship toward world stock markets is of significance at this stage as those of African stock markets have already been explored.

Table 7: Long-Run Cointegration Relationship Results (World and African Stock Markets)

\begin{tabular}{|c|c|c|c|c|c|c|c|c|c|}
\hline \multirow{2}{*}{$\begin{array}{l}\text { Dependent } \\
\text { Variable } \\
\text { (LSA) }\end{array}$} & \multicolumn{9}{|c|}{ Independent Variables } \\
\hline & LBotswana & LMauritius & LNamibia & LNigeria & Dum & LGermany & LJapan & LUSA & C \\
\hline Coefficient & $0.080 * *$ & $-0.895 * *$ & $-0.541 * *$ & $0.194 * *$ & $0.477 * *$ & $-2.388 * *$ & $-0.427 * *$ & $4.890 * *$ & -13.979 \\
\hline $\begin{array}{l}\text { Standard } \\
\text { Errors }\end{array}$ & $(0.140)$ & $(0.246)$ & $(0.209)$ & $(0.142)$ & $(0.133)$ & $(0.353)$ & $(0.221)$ & $(0.612)$ & \\
\hline t-statistics & [ 0.573$]$ & {$[-3.635]$} & {$[-2.590]$} & [ 1.365$]$ & [3.591] & {$[-6.762]$} & {$[-1.928]$} & [ 7.985] & \\
\hline
\end{tabular}

(Source: Author's Computation)

$*, * *, * * *$ imply $10 \%, 5 \%$ and $1 \%$ significance levels, respectively.

The cointegration relationship shows that JSE has a positive relationship with the USA. Thus, the JSE is positively linked with the US and negatively linked with Germany and Japan as the test co-efficients of the latter markets are negative. The short-run dynamics estimated using the Error correction model prove that there is a positive relationship between South Africa and Japan. Also, in the short run, the USA and JSE stock markets have a negative relationship. Thus, the model reveals a self-correcting mechanism.

As shown in the impulse response results (in Appendix 1), SEM and NSX respond positively to the world stock markets. However, the BSE and NSE trivially respond to the world stock markets. Probably as postulated by Alagidede (2008), the latter African stock markets respond insignificantly to the world stock markets as most of the trading happens in the South African stock market.

Evidence from the impulse response function somewhat concurs with the evidence gathered by Alagidede (2008), whilst the author investigated the relationship between African stock markets and the rest of the world. Although the countries under investigation differ from the ones investigated in this study, the South African stock market proves to be operating in an open economy and the level of macroeconomic coordination between the countries is very high. Also, African stock markets, such as BSE and NSX, stand a good chance to be linked with the world stock markets as they are linked to the JSE and most of their trading occurs in the JSE. This is supported with the findings of Mlambo and Biekpe (2007).

\section{SUMMARY AND CONCLUSION}

The study has attempted to answer most of the questions about the level of integration within the African stock markets. Trends and the overall characteristics of the African stock markets were explored in detail. Of importance on the trends and development of the African stock markets is that considerable improvements can be noted and appreciated as more and more stock markets have and are being established. Market performance has grown as well, thanks to the trade liberalisation efforts from the concerned authorities. However, as much as the 
positive is evidenced, African stock markets are still illiquid, lack economies of scale and are segmented. Markets such as the JSE are the African giants and perform considerably well compared to the world and regional stock markets.

External investors find it hard to invest in African stock markets, except for the JSE, due to the illiquidity of the markets and the political ups and downs. Empirical literature has shown the advantages and disadvantages of stock market integration and few studies have been conducted in the case of Africa. Little or few studies link African stock markets with the rest of the world; more of the studies focus on the JSE and the world economy as it is the best performing market in Africa. However, organisations, such as the ASEA (African securities Exchange Association), are trying all they can to ensure the development of more African stock markets and improve the competitiveness of the already existing ones.

Empirical results reveal that there is a single cointegration relationship in the series. The Vector error correction model was estimated and the short-run positive relationship was noted between the JSE and BSE. Also the VAR Granger causality/Wald Exogeinity test revealed that African stock markets are still not fully integrated. These results concur with Alagidede (2008), Agyei-Ampomah (2011) and Adebola \& Dahalan (2012). However, results show that arbitrage opportunities exist between the African stock markets. The variance decomposition and impulse response results reveal that the JSE index has much influence on the BSE index but the markets are still segmented from each other, mainly because of the difference in operational capacity and efficiency in the markets. Nonetheless, much is being done in the BSE as a growing market to harmonise all its trades with the African stock market giant.

Also, a weak stochastic trend was evidenced between African stock markets and the rest of the world, except for the JSE, as evidenced by the impulse response results. Further, obtained results show that African stock markets are not interlinked and they are not affected by world events as the well-established world stock markets. The weak link may be due to limited cooperation between Africa and the rest of the world through international trade. The study further notes that another possible cause of lack of integration between the African stock markets is the use of different currencies and, hence, arbitrage profits emerge from exchange differentials. Thus, exchange differential should be eliminated to achieve the law of one price within African stock markets.

\section{AUTHOR INFORMATION}

Gail Ncube is a Master of Economics graduate from the University of Fort Hare, East London Campus, and an aspiring Ph.D. student in the field of economics. Her research area is in Financial Markets and Monetary Economics and she also has interest in International Finance and Development Finance.

Forget Mingiri Kapingura is a Lecturer and a Ph.D. student at the University of Fort Hare, East London campus. His research area is in International Finance, Development Finance and economic growth in emerging markets and he also has interest in financial markets and monetary economics.

\section{REFERENCES}

Abraham, T. W. (2009). Stock Market Reaction to Selected Macroeconomic Variables in the Nigerian Economy. CBN Journal of Applied Statistics Vol. 2(1), pp 61-70.

Adebola, S. S., \& Dahalan, J. (2012). An Empirical Analysis of Stock Markets Integration in Selected African Countries. Euro Ec o no mic a. Issue 2(31).

Agyei-Ampomah, S. (2011). Stock market integration in Africa Managerial Finance, 37 (3). p. 242-256 . University of Surrey, UK.

Akinlo, E. A., \& Akinlo, O. O. (2009). Stock Market Development and Economic Growth: Evidence from Seven Sub-Saharan African Countries. Journal of Economics and Business, Vol. 61 (2), pp. 162-171.

Alagidede, P. (2008). African Stock Market Integration: Implications for Portfolio Diversification and International Risk Sharing. Stirling Management School. UK.

Alagidede, P. (2009). Randomness and Non-linear Dependence in African Equity Markets. African Review of Economics and Finance. Vol. 1(1). pp. 1-17. 
Allen, F., Otchere, I., \& Senbet, L. W. (2010). African Financial Systems: A Review. Nomura Institute of Capital Markets Research.

Arouri, M. E. H. (2012). Are Stock Markets Integrated? Evidence from a Partially Segmented ICAPM with Asymmetric Effects. LEO \& EconomiX, University of Paris X, France.

Arouri, M. E. H., \& Jawadi, F. (2009). Stock Market Integration in Emerging Countries: Further Evidence from the Philippines and Mexico. Amiens Graduate Business School and EconomiX-CNRS-University of Paris.

Ayuso, J., \& Blanco, R. (1999). Has Financial Market Integration Increased During the Nineties? Banco de España Research Department.

Babetskii, I., Komarek, L., \& Komarkova, Z. (2007). Financial Integration of Stock Markets among New EU Member States and the Euro Area. Czech Journal of Economics and Finance, 57 (7-8).

Bartram, S. M., Taylor, S. J., \& Wang, Y. H. (2006). The Euro and European Financial Market Integration. Lancaster University, Management School. UK.

Baumohl, E. (2013). Stock market integration between the CEE-4 and the G7 markets: Asymmetric DCC and smooth transition approach. MPRA Paper No. 43834.

Berben, R. P., \& Jansen, W. J. (2005). Bond Market and Stock Market Integration in Europe. DNB Working Paper No. 060/2005.

Berger, T., \& Pozzi, L. (2012). Measuring time-varying financial market integration: An unobserved components approach. Elsevier.

Breitung, J. (2001). Rank Test for Nonlinear Cointegration. Journal of Business \& Economic Statistics. Vol. 19 (3) pp. 331-340.

Brooks, C. (2008). Introductory Econometrics for Finance. $2^{\text {nd }} e d$. Cambridge University Press.

Buttner, D., \& Hayo, B. (2008). Determinants of European Stock Market Integration. Joint Discussion Paper Series in Economics. Paper 32-2009.

Bunyi, R. (2003). Africa's Equity Markets - A Synopsis. African Stock Markets Handbook, 2003. UNDP.

Cerny, A. (2004). Stock Market Integration and the Speed of Information Transmission. CERGE-EI Working Paper Series (ISSN 1211-3298).

Chuang, W. J., Ouang, L. Y., \& Lo, W. C. (2010). The Impact of Investor Sentiment on Excess Returns: A Taiwan Stock Market Case. International Journal of Information and Management Sciences 21 (2010), 13-28. Retrieved from www. ijims.ms.tku.edu.tw/list.asp.

Darrat, A. F., Ekhal, K., \& Hakim, S. R. (2000). On the Integration of Emerging Stock Markets in the Middle East. Journal of Economic Development. Vol 25(2).

Dahou, K., Omar, H. I., \& Pfister, M. (2009). Deepening African Financial Markets for Growth and Investment. NEPAD-OECD. Africa Investment Initiative.

Engle, R., \& Granger, C. (1987). Co-Integration and Error Correction: Representation, Estimation, and Testing. Econometrica Vol. 55, pp. 251-275.

Fratzscher, M. (2001). Financial Market Integration in Europe: On the Effects of EMU Stock markets. International Journal of Finance and Economics. Vol 7(3). WP 48. Retrieved from www.ebc.europu.eu/pub.

Granger, C. W. J. (1969). Investigating Causal Relations by Econometric Models and Cross-Spectral Methods. Econometrica 37, 424-38.

Guesmi, K. (2011). Time varying regional integration in emerging stock market. Economics Bulletin. Vol 31 (2).

Hlophe, S., Stokoe, G., Bunder, J., Rogers, M., \& Date, S. (2014). Private Equity Round Up: Africa 2014. Retrieved from www.ey.com.

Jain, S., \& Bhanumurthy, N. R. (2005). Financial Markets Integration in India. Asia-Pacific Development Journal Vol. $12(2)$.

Johansen, S. (1995). Likelihood-based Inference in Cointegrated Vector Autoregressive Models. Oxford University Press. Oxford.

Johansson, A. C. (2009). China's Financial Market Integration with the World. CERC Working Paper 10.

Kao, M. Y., \& Tate, S. R. (2001). Designing Proxies for Stock Market Indices is Computationally Hard. Quantitative Finance, Vol 1(3), pp 361-371.

Karim, Z. A., \& Karim, B. A. (2008). Stock market integration: Malaysia and its Major Trading Partners. MPRA Paper No. 26976. Available on website: http://mpra.ub.uni-muenchen.de/26976/.

Massa, I. (2009). Stock Markets in Africa: Bidding for Growth amid Global Turmoil. ODI ISSN 1756-76 29. Retrieved from www.odi.org.uk.

Melle, M. (2001). The Euro Effect on the Integration of the European Stock Markets. Universidad Complutense de 
Madrid. Spain.

Mlambo, C., \& Biekpe, N. (2007). The Efficient Market Hypothesis: Evidence from ten African Stock Markets. Investment Journal No. 66.

Mukherjee, K. N., \& Mishra, R. K. (2005). Stock Market Inter-linkages: A Study of Indian and World Equity Markets.

Neame, S. (2002). Liberalization and Financial Integration of MENA Stock Markets. Institute of Financial Economics American University of Beirut.

Nkontchou, C. (2010). Africa's Financial Markets: A real development tool? Recent Evolution of the African Financial Markets. Issue 5. Retrieved from www.enkocapital.com/downloads/private-SectorDevelopment.pdf.

Ntim, C. G. (2012). Why African Stock Markets Should Formally Harmonise and Integrate their Operations. African Review of Economics and Finance, Vol. 4 (1).

Ntim, C. G., Opong, K. K., Danbolt, J., \& Dewotor, F. (2011). Testing the Weak-Form in African Stock Markets. Managerial Finance, Vol. 37 (3). pp. 195-218.

Onour, I. (2009). Financial Integration of North Africa Stock Markets. MPRA Paper No. 14938. Retrieved from http://mpra.ub.uni-muenchen.de/14938/.

Pukthuanthong, J., \& Roll, R. (2009). Global Market Integration: An Alternative Measure and Its Application. Journal of Financial Economics, Vol. 94, pp. 214-232.

Raj, J., \& Dhal, S. (2009). Integration of India's Stock Market with Global and Major Regional Markets. BIS Papers No 42.

Sims, C. (1980). Macroeconomics and Reality. Econometrica 48, pp. 1-49.

Srikanth, P. (2012). Integration of Indian Stock Market with Other Markets in the Asian-Pacific Region. The IUP Journal of Financial Economics, $\operatorname{Vol} X(1)$.

Srikanth, P., \& Aparna, K. (2012). Global Stock Market Integration - A Study of Select World Major Stock Markets. International Refereed Research Journal. Vol. III (1).

Tam, P. S., \& Tam, P. I. (2012). Rethinking stock market integration: Globalization, valuation and convergence. Discussion Paper 2012-052.

Wang, P., \& Moore, T. (2008). Stock Market Integration for The Transition Economies: Time-Varying Conditional Correlation Approach. Blackwell Publishing Ltd.

Wong, W. K., Agarwald, A., \& Du, J. (2003). Financial Integration for India Stock Market, a Fractional Cointegration Approach. National University of Singapore. Working Paper No. 0501.

World Data Bank. (2013). World Development Indicators. Retrieved from http://databank.worldbank.org/data/views/variableSelection/selectvariables.aspx?source=worlddevelopment-indicators.

Yartey, C. A., \& Adjasi C. K. (2007). Stock Market Development in Sub-Saharan Africa: Critical Issues and Challenges. IMF Working Paper 07/209. Washington, DC: International Monetary Fund.

Yoshida, Y. (2009). Financial crisis, exchange rate and stock market integration. Kyushu Sangyo University. Discussion Paper No.38. 


\section{APPENDIX 1}

Response to Cholesky One S.D. Innovations

Response of LSA to LSA

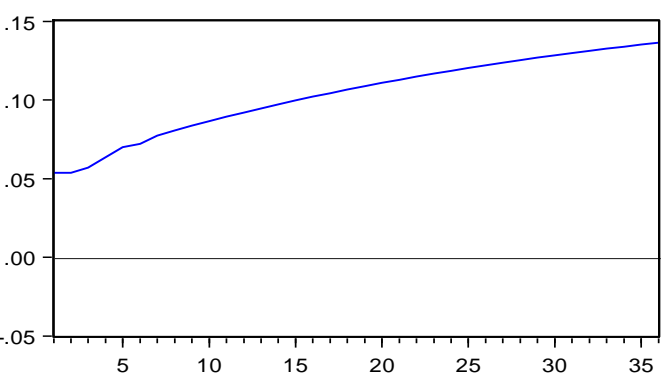

Response of LSA to LNAMIBIA

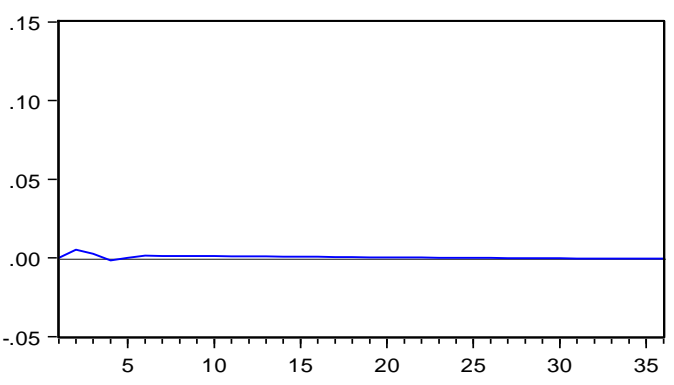

Response of LSA to LGERMAN

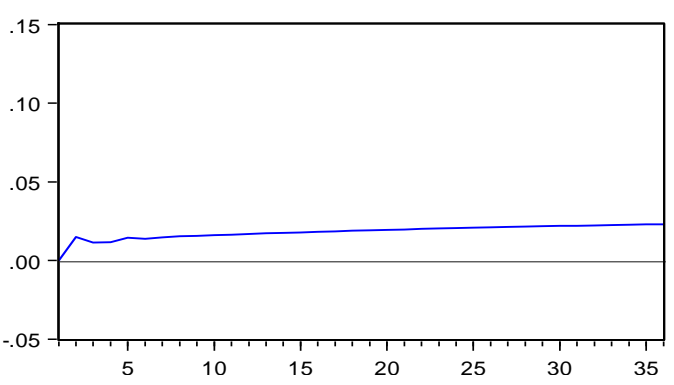

Response of LSA to LBOTSWANA

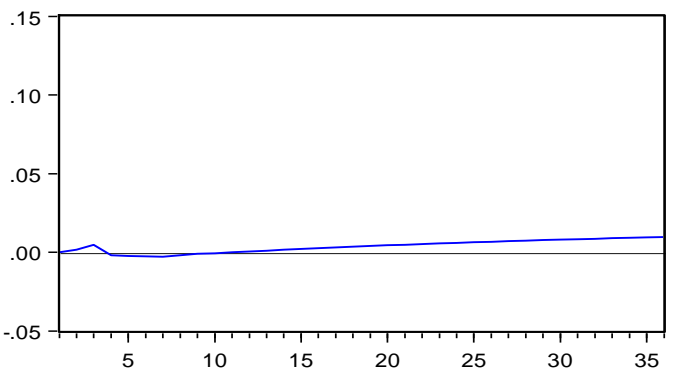

Response of LSA to LNIGERIA

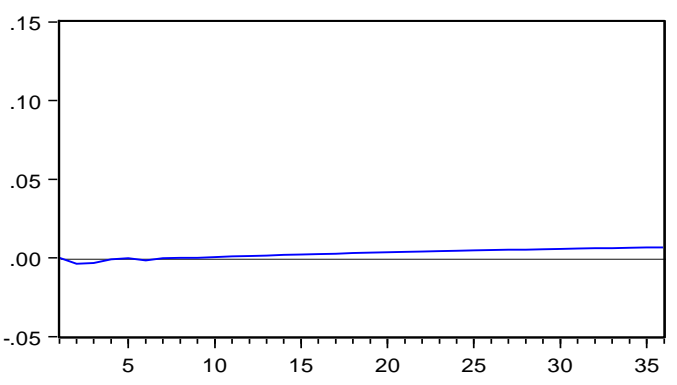

Response of LSA to LJAPAN

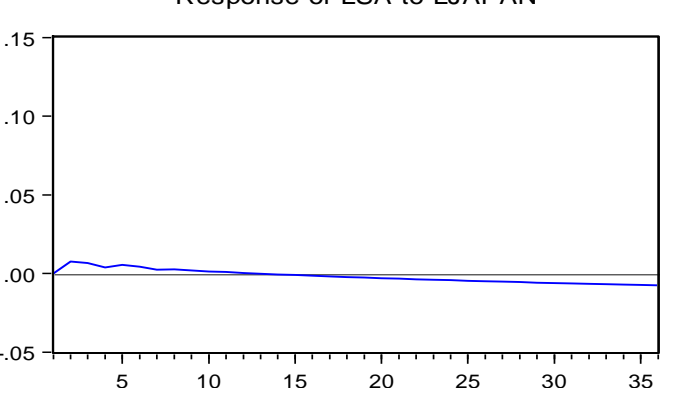

Response of LSA to LMAURITIUS

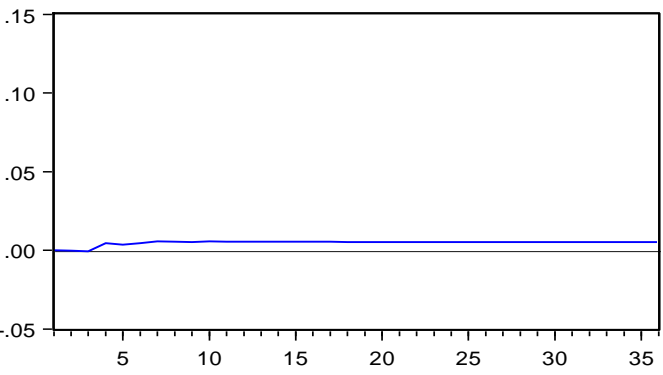

Response of LSA to DUM

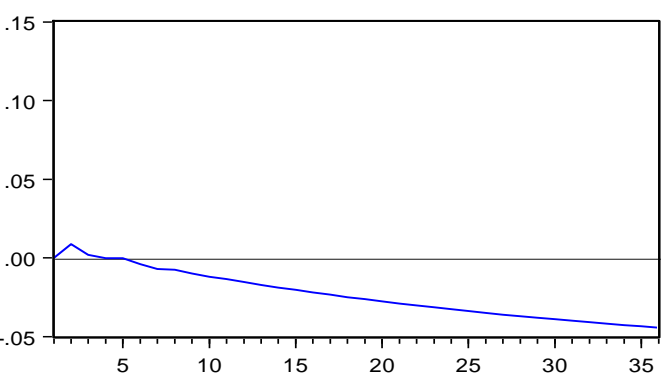

Response of LSA to LUSA

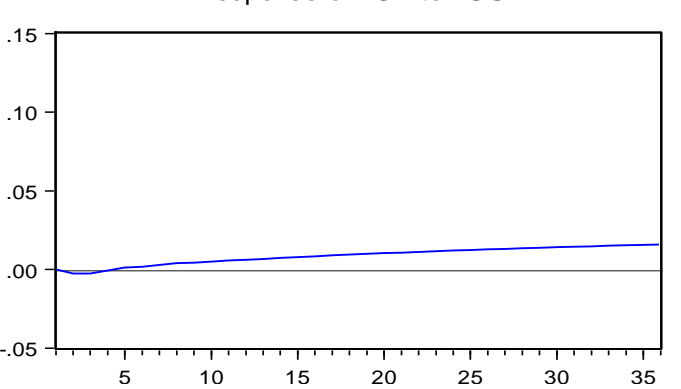




\section{APPENDIX 2}

\begin{tabular}{|c|c|c|c|c|c|c|c|}
\hline \multicolumn{8}{|c|}{ Variance Decomposition: LSA } \\
\hline Period & S.E & LSA & LBOTS & LMAUR & LNAM & LNIG & DUM \\
\hline 1 & 0.05 & 100.00 & 0.00 & 0.00 & 0.00 & 0.00 & 0.00 \\
\hline 2 & 0.08 & 97.17 & 0.51 & 0.03 & 0.00 & 0.14 & 2.16 \\
\hline 3 & 0.09 & 95.90 & 1.32 & 0.02 & 0.01 & 0.16 & 2.60 \\
\hline 4 & 0.11 & 94.84 & 2.23 & 0.01 & 0.01 & 0.15 & 2.76 \\
\hline 5 & 0.12 & 93.87 & 3.14 & 0.01 & 0.01 & 0.14 & 2.83 \\
\hline 6 & 0.13 & 93.00 & 4.00 & 0.01 & 0.01 & 0.13 & 2.85 \\
\hline 7 & 0.14 & 92.23 & 4.77 & 0.01 & 0.01 & 0.12 & 2.86 \\
\hline 8 & 0.15 & 91.57 & 5.45 & 0.01 & 0.01 & 0.11 & 2.86 \\
\hline 9 & 0.16 & 90.99 & 6.04 & 0.01 & 0.01 & 0.11 & 2.85 \\
\hline 10 & 0.17 & 90.49 & 6.55 & 0.01 & 0.01 & 0.10 & 2.84 \\
\hline 11 & 0.18 & 90.06 & 6.99 & 0.01 & 0.01 & 0.10 & 2.84 \\
\hline 12 & 0.19 & 89.70 & 7.37 & 0.004 & 0.01 & 0.09 & 2.83 \\
\hline \multicolumn{8}{|c|}{ Variance Decomposition: LBotswana } \\
\hline Period & S.E & LSA & LBOTS & LMAUR & LNAM & LNIG & DUM \\
\hline 1 & 0.03 & 0.35 & 99.65 & 0.00 & 0.00 & 0.00 & 0.00 \\
\hline 2 & 0.05 & 1.06 & 98.18 & 0.03 & 0.02 & 0.54 & 0.17 \\
\hline 3 & 0.08 & 2.16 & 95.53 & 0.06 & 0.11 & 1.49 & 0.64 \\
\hline 4 & 0.09 & 3.57 & 92.13 & 0.109 & 0.28 & 2.59 & 1.35 \\
\hline 5 & 0.11 & 5.20 & 88.24 & 0.13 & 0.49 & 3.71 & 2.21 \\
\hline 6 & 0.13 & 7.00 & 84.09 & 0.17 & 0.75 & 4.80 & 3.18 \\
\hline 7 & 0.14 & 8.88 & 79.85 & 0.21 & 1.03 & 5.82 & 4.21 \\
\hline 8 & 0.15 & 10.77 & 75.66 & 0.24 & 1.31 & 6.76 & 5.25 \\
\hline 9 & 0.16 & 12.63 & 71.63 & 0.27 & 1.60 & 7.61 & 6.27 \\
\hline 10 & 0.17 & 14.40 & 67.82 & 0.29 & 1.87 & 8.37 & 7.24 \\
\hline 11 & 0.18 & 16.07 & 64.29 & 0.31 & 2.13 & 9.03 & 8.16 \\
\hline 12 & 0.19 & 17.62 & 61.04 & 0.33 & 2.37 & 9.62 & 9.01 \\
\hline \multicolumn{8}{|c|}{ Variance Decomposition: LMauritius } \\
\hline Period & S.E & LSA & LBOTS & LMAUR & LNAM & LNIG & DUM \\
\hline 1 & 0.03 & 0.01 & 0.00 & 100.00 & 0.00 & 0.00 & 0.00 \\
\hline 2 & 0.05 & 0.50 & 1.51 & 95.51 & 0.04 & 1.58 & 0.87 \\
\hline 3 & 0.07 & 0.31 & 5.04 & 90.68 & 0.07 & 2.692 & 1.21 \\
\hline 4 & 0.08 & 0.30 & 9.67 & 85.69 & 0.06 & 3.21 & 1.08 \\
\hline 5 & 0.10 & 0.47 & 14.60 & 80.67 & 0.04 & 3.35 & 0.87 \\
\hline 6 & 0.11 & 0.74 & 19.34 & 75.88 & 0.04 & 3.31 & 0.69 \\
\hline 7 & 0.12 & 1.06 & 23.63 & 71.54 & 0.04 & 3.19 & 0.55 \\
\hline 8 & 0.13 & 1.37 & 27.37 & 67.71 & 0.05 & 3.04 & 0.46 \\
\hline 9 & 0.15 & 1.65 & 30.58 & 64.41 & 0.06 & 2.90 & 0.39 \\
\hline 10 & 0.16 & 1.91 & 33.31 & 61.58 & 0.08 & 2.77 & 0.35 \\
\hline 11 & 0.17 & 2.13 & 35.62 & 59.18 & 0.09 & 2.66 & 0.32 \\
\hline 12 & 0.18 & 2.32 & 37.59 & 57.13 & 0.10 & 2.56 & 0.31 \\
\hline
\end{tabular}




\begin{tabular}{|c|c|c|c|c|c|c|c|}
\hline \multicolumn{8}{|c|}{ Variance Decomposition: LNamibia } \\
\hline Period & S.E & LSA & LBOTS & LMAUR & LNAM & LNIG & DUM \\
\hline 1 & 0.02 & 0.01 & 0.13 & 2.41 & 97.45 & 0.00 & 0.00 \\
\hline 2 & 0.03 & 0.25 & 0.08 & 1.58 & 97.86 & 0.24 & 0.00 \\
\hline 3 & 0.04 & 1.13 & 0.39 & 1.23 & 96.93 & 0.23 & 0.08 \\
\hline 4 & 0.05 & 2.27 & 1.20 & 1.02 & 95.00 & 0.18 & 0.33 \\
\hline 5 & 0.05 & 3.48 & 2.46 & 0.86 & 92.38 & 0.14 & 0.68 \\
\hline 6 & 0.06 & 4.62 & 4.02 & 0.75 & 89.43 & 0.12 & 1.07 \\
\hline 7 & 0.07 & 5.64 & 5.72 & 0.65 & 86.41 & 0.12 & 1.45 \\
\hline 8 & 0.07 & 6.52 & 7.44 & 0.58 & 83.53 & 0.13 & 1.80 \\
\hline 9 & 0.08 & 7.26 & 9.09 & 0.52 & 80.88 & 0.14 & 2.11 \\
\hline 10 & 0.09 & 7.88 & 10.62 & 0.47 & 78.49 & 0.15 & 2.38 \\
\hline 11 & 0.09 & 8.40 & 12.02 & 0.43 & 76.38 & 0.16 & 2.61 \\
\hline 12 & 0.10 & 8.83 & 13.27 & 0.40 & 74.52 & 0.17 & 2.80 \\
\hline \multicolumn{8}{|c|}{ Variance Decomposition: LNigeria } \\
\hline Period & S.E & LSA & LBOTS & LMAUR & LNAM & LNIG & DUM \\
\hline 1 & 0.05 & 1.56 & 0.02 & 0.98 & 0.11 & 97.33 & 0.00 \\
\hline 2 & 0.09 & 1.55 & 0.16 & 0.74 & 0.53 & 96.07 & 0.95 \\
\hline 3 & 0.12 & 1.27 & 0.41 & 0.74 & 0.78 & 95.49 & 1.31 \\
\hline 4 & 0.14 & 1.06 & 0.73 & 0.76 & 0.90 & 95.14 & 1.42 \\
\hline 5 & 0.16 & 0.90 & 1.13 & 0.77 & 0.94 & 94.84 & 1.42 \\
\hline 6 & 0.18 & 0.77 & 1.56 & 0.78 & 0.95 & 94.55 & 1.39 \\
\hline 7 & 0.19 & 0.67 & 2.00 & 0.79 & 0.94 & 94.26 & 1.34 \\
\hline 8 & 0.21 & 0.59 & 2.44 & 0.79 & 0.93 & 93.96 & 1.29 \\
\hline 9 & 0.22 & 0.52 & 2.86 & 0.79 & 0.91 & 93.67 & 1.24 \\
\hline 10 & 0.24 & 0.47 & 3.25 & 0.79 & 0.90 & 93.39 & 1.20 \\
\hline 11 & 0.25 & 0.42 & 3.62 & 0.79 & 0.88 & 93.13 & 1.16 \\
\hline 12 & 0.26 & 0.39 & 3.95 & 0.79 & 0.87 & 92.88 & 1.12 \\
\hline \multicolumn{8}{|c|}{ Variance Decomposition: Dum } \\
\hline Period & S.E & LSA & LBOTS & LMAUR & LNAM & LNIG & DUM \\
\hline 1 & 0.10 & 1.40 & 2.04 & 0.29 & 1.13 & 0.11 & 95.03 \\
\hline 2 & 0.14 & 3.71 & 3.48 & 0.21 & 2.63 & 0.19 & 89.77 \\
\hline 3 & 0.17 & 4.99 & 4.15 & 0.20 & 3.04 & 0.25 & 87.36 \\
\hline 4 & 0.19 & 6.41 & 4.22 & 0.20 & 3.15 & 0.23 & 85.80 \\
\hline 5 & 0.21 & 8.01 & 3.96 & 0.19 & 3.13 & 0.20 & 84.52 \\
\hline 6 & 0.23 & 9.69 & 3.57 & 0.18 & 3.04 & 0.17 & 83.34 \\
\hline 7 & 0.25 & 11.38 & 3.17 & 0.18 & 2.94 & 0.15 & 82.19 \\
\hline 8 & 0.26 & 13.03 & 2.82 & 0.17 & 2.82 & 0.14 & 81.02 \\
\hline 9 & 0.27 & 14.61 & 2.55 & 0.16 & 2.70 & 0.14 & 79.85 \\
\hline 10 & 0.29 & 16.07 & 2.36 & 0.16 & 2.59 & 0.14 & 78.68 \\
\hline 11 & 0.30 & 17.43 & 2.25 & 0.15 & 2.48 & 0.14 & 77.55 \\
\hline 12 & 0.31 & 18.66 & 2.20 & 0.15 & 2.38 & 0.14 & 76.47 \\
\hline
\end{tabular}

